\title{
Balanced system of indicators for the assessment of innovative construction projects efficiency
}

\author{
Saule Rakhimova ${ }^{1, *}$, Kymbat Kunanbayeva ${ }^{2}$, Lyudmila Goncharenko ${ }^{3}$, and Andrey Pigurin ${ }^{4}$ \\ ${ }^{1}$ S. Toraighyrov Pavlodar State University, 140008, 64 Lomov Str., Pavlodar, Republic of Kazakhstan \\ ${ }^{2}$ Financial university under the Government of the Russian Federation, 125993, 49, Leningradsky \\ Prospekt, Moscow, Russia \\ ${ }^{3}$ Plekhanov Russian University of Economics, 117997, 36, Stremyanny lane, Moscow, Russia \\ ${ }^{4}$ Moscow State University of Civil Engineering, 129337, 26, Yaroslavskoe Shosse, Moscow, Russia
}

\begin{abstract}
The role of innovations in the construction industry is considered in the article. In the conditions of transition of national economy to the innovative type of development, the indicators that allow estimating the efficiency of innovative activity, where the key aspect is the comprehensive assessment, are important. Innovative projects are especially relevant for the construction industry, which is the key driver of the national economy development. Sustainable construction ensures the development of industries, where innovative projects can partly solve the problems of creating renewable energy sources. The authors offer to expand the list of indicators for the assessment of the innovative project efficiency not only from the financial and investment point of view, but also taking into account quantitative and quality, scientific, technological, operational, marketing indicators, which often are not considered. The assessment of the innovative projects efficiency has to be the central link in the innovation management; so the authors offer to improve the system of the balanced indicators. The balanced system of indicators (BSI) is developed. It is planned to extend and to introduce BSI not only at the level of the enterprises, but also for all the types of economic activity according to their technological effectiveness.
\end{abstract}

\section{Introduction}

At the present stage, digital technologies develop actively on the basis of information revolution and processes of globalization. Nowadays, the main factor of activity of the market subjects is digitalization of business processes and management processes. Thus, transformation affects all the levels, sectors and branches of the economy. Digitalization of business processes increases the effectiveness of the economic entities activity and has the huge potential of assistance of the economic development. In the conditions of digital economy, the role of innovative projects is of particular importance as, using information and

\footnotetext{
${ }^{*}$ Corresponding author: KKunanbaeva@fa.ru
} 
digital technologies, subjects of the market increase the efficiency and competitiveness of the national economy on the basis of innovative development.

According to RBC information company, such activities as Big data, Internet of things, cloud computing, robotics, "clever clothes", etc. will be relevant in the next 3-5 years. Modern business adapts to the introduction of the IT-solution in production now. For example, in 2012 the programme of Electronic development of assets which is aimed at the increase in the level of automation of exploration and production started in Gazprom Neft [6].

Nowadays, the development strategy of information society of the Russian Federation for 2017-2030 (digital economy), where the key attention is paid to the issues of innovative development, is implemented in the country. In 2017 the special road map Tekhnet, which provides support of the advanced production technologies was accepted and the development programme of digital economy till 2024 was also prepared. The development of financial technologies is carried out by the means of creation of Fintech association united the key players of the domestic financial market.

In this regard, considering high relevance of the innovative development in the conditions of digital economy, authors carried out the research on identification of features of application of the existing approaches to the assessment of the innovative project efficiency. Authors offered an advanced technique for the assessment of the innovative projects efficiency on the basis of the balanced system of indicators, traditional projections are expanded and features of digital economy are considered.

\section{Materials and Methods}

The effective investment policy is crucial for the strategic development of economic entities, where the key role is played by innovative projects. The implementation of innovative projects as the means of ensuring high added value demands comprehensive study and justification, as the need of the solution of the problem of the choice of the best innovative projects demands effective tools of the assessment. The innovative project represents a complex system, interdependent and interconnected on resources, terms and performers of the measures, directed to the achievement of the priority purposes of the organizations.

There are some methodical receptions of the assessment of the innovative project efficiency, such as the method of the analysis of hierarchies, which allows receiving a calculated value of the integrated indicator as the selection criterion of the perspective project [1].

Now some indicators for the assessment of the innovative project efficiency, which reflect a ratio of expenses and results, are used:

- net discounted income or integrated effect (the other name of the indicator which is quite widely used abroad is net discounted net present value (NPV);

- profitability index (PI);

- internal rate of return or internal rate of profitability (IRR);

- payback period or term of return of one-time costs (PBP) [2].

Assessment of the innovative project efficiency has to be the central link in the mechanism of innovations management. In the modern conditions, the mechanism of innovations management is a weak link of organizational-and-economic structure of management in the domestic organizations. It is explained not only with high degree of variability of the external environment, unsystematized work of all services of the organization, but also with the lack of system approach to the assessment of innovative activity and also considerable discrepancy of the current purposes of the company with the stated strategy for the reason of misunderstanding of a strategic objective and the tasks facing the company, employees of the organization. In this situation, it is important for managers to 
focus on the limited number of questions, important for business. It actually cannot be made in case of the absence in the organization of the formalized system, tracing the key indicators and allowing the influence on the basis of this information realization of strategy of business. International experience proves that most the companies solve this problem by introduction of the balanced system of indicators (BSI) [3].

Modern scientists supplement the system of the balanced indicators, expanding the projections and including additional indicators, and thus, altering BSI, offered by Kaplan and Norton. The analysis of works of researchers in the field allows to conclude that often even more often the innovative component is pointed out in the balanced system of indicators as the separate aspect $[4,5]$.

Today, the assessment of the innovative project efficiency is carried out only from the financial point of view, i.e. through the key aforesaid indicators, without agreement with the key quality and quantitative indices research, technological, production, personnel, market, client, marketing and other components which in our opinion, are important during receiving innovations. We receive innovations process by process $[7,8,9]$. According to the model of innovative processes management, the main stages are research and development (RD), production of innovations, commercialization of innovations. That are the initial components for the implementation of the innovative project are the cost of research and development, cost of the organization of production, and cost of commercialization of innovations. And, it is important to consider that all the stages have to proceed in the conditions of the digitalization of the economy.

The structure, logic and communication among the purposes, indicators and actions for management of innovative process and effective implementation of the innovative project have to be traced accurately in the BSI, it is also necessary for the establishment of the causeand-effect relationships of the influence of indicators on the result of innovative activity [10].

Tables 1-4 present purposes, indicators and actions of the basic scheme of BSI (finance/economy, clients/market, business processes, personnel).

Table 1. Purposes, indicators, actions for the "Finance" projection

\begin{tabular}{|l|l|l|}
\hline \multicolumn{1}{|c|}{ Purpose } & \multicolumn{1}{|c|}{ Indicators } & \multicolumn{1}{c|}{ Measures } \\
\hline $\begin{array}{l}\text { To increase the profitability } \\
\text { of the enterprise due to the } \\
\text { reorientation from traditional } \\
\text { to innovative production }\end{array}$ & $\begin{array}{l}\text { Net profit from the } \\
\text { production of innovations, } \\
\text { thousand rubles }\end{array}$ & $\begin{array}{l}\text { To reduce managerial costs, to } \\
\text { raise profit from production of } \\
\text { innovations, to raise profit per one } \\
\text { worker }\end{array}$ \\
\hline $\begin{array}{l}\text { To raise income from } \\
\text { innovative products, services } \\
\text { (innovative goods and } \\
\text { services) }\end{array}$ & $\begin{array}{l}\text { Income from selling of } \\
\text { innovative products, } \\
\text { rendering services of } \\
\text { innovative character, } \\
\text { thousand rubles }\end{array}$ & $\begin{array}{l}\text { Release of competitive innovative } \\
\text { products, rendering services of } \\
\text { innovative character }\end{array}$ \\
\hline $\begin{array}{l}\text { To raise income from new } \\
\text { clients (new markets) }\end{array}$ & $\begin{array}{l}\text { Income from the } \\
\text { involvement of new clients } \\
\text { (new sales markets), } \\
\text { thousand rubles }\end{array}$ & To increase the market share \\
\hline $\begin{array}{l}\text { To raise profit per one } \\
\text { worker }\end{array}$ & $\begin{array}{l}\text { Profit per one worker, } \\
\text { thousand rubles }\end{array}$ & $\begin{array}{l}\text { To increase the efficiency of the } \\
\text { use of human resources }\end{array}$ \\
\hline $\begin{array}{l}\text { To raise income from the use } \\
\text { of digital technologies }\end{array}$ & $\begin{array}{l}\text { Effect of the use of digital } \\
\text { technologies (relation of } \\
\text { income from the use of } \\
\text { digital technologies to } \\
\text { expenses) }\end{array}$ & $\begin{array}{l}\text { To develop the strategy of the use } \\
\text { of digital technologies for stages } \\
\text { of innovative process }\end{array}$ \\
\hline
\end{tabular}

According to Table 1, we can see that the financial component is connected with clients/consumers, innovative processes, employees/workers. 
The purposes, indicators and actions of the basic scheme of BSI (clients/market) are presented in Table 2 [11].

Table 2. Purposes, indicators, actions for the "Clients/market"

\begin{tabular}{|l|l|l|}
\hline \multicolumn{1}{|c|}{ Purpose } & \multicolumn{1}{|c|}{ Indicators } & \multicolumn{1}{c|}{ Measures } \\
\hline $\begin{array}{l}\text { To increase the customers' } \\
\text { satisfaction }\end{array}$ & $\begin{array}{l}\text { Quantity of the innovative } \\
\text { projects carried out in time } \\
\text { and according to conditions } \\
\text { and requirements of clients }\end{array}$ & $\begin{array}{l}\text { To develop and implement the } \\
\text { methods of stimulation and } \\
\text { motivation through the system of } \\
\text { responsibility and remuneration } \\
\text { for the performance of indicators }\end{array}$ \\
\hline To hold the actual clients & $\begin{array}{l}\text { Sales volume to the existing } \\
\text { actual, not potential) to } \\
\text { clients of goods and services } \\
\text { of traditional production, } \\
\text { thousand rubles }\end{array}$ & $\begin{array}{l}\text { To increase the level of service for } \\
\text { clients with sounding of their } \\
\text { preferences and opportunities of } \\
\text { gradual transition to the } \\
\text { innovative products and rendering } \\
\text { services of innovative character }\end{array}$ \\
\hline $\begin{array}{l}\text { To increase the market share } \\
\text { due to the sale of innovative } \\
\text { goods and services }\end{array}$ & $\begin{array}{l}\text { Sales volume of innovative } \\
\text { goods and services, thousand } \\
\text { rubles }\end{array}$ & $\begin{array}{l}\text { To develop marketing policy on } \\
\text { the innovative goods and services } \\
\text { promotion in the market }\end{array}$ \\
\hline $\begin{array}{l}\text { To increase the market share } \\
\text { due to the involvement of } \\
\text { new clients }\end{array}$ & $\begin{array}{l}\text { Sales volume of innovative } \\
\text { goods and services to new } \\
\text { clients, thousand rubles }\end{array}$ & $\begin{array}{l}\text { Pointed work with the potential } \\
\text { clients, consumers, development } \\
\text { of strategy of the involvement of } \\
\text { new clients }\end{array}$ \\
\hline
\end{tabular}

The purposes, indicators and actions of the basic scheme of BSI (Internal processes) are presented in Table 3.

Table 3. Purposes, indicators, actions for the "Internal processes" projection

\begin{tabular}{|l|l|l|}
\hline \multicolumn{1}{|c|}{ Purpose } & \multicolumn{1}{|c|}{ Indicators } & \multicolumn{1}{c|}{ Measures } \\
\hline $\begin{array}{l}\text { Production of a "turnkey" } \\
\text { innovation }\end{array}$ & $\begin{array}{l}\text { Share of cost of goods and } \\
\text { services, thousand rubles }\end{array}$ & $\begin{array}{l}\text { Implementation of goods and services at } \\
\text { the expense of own potential and / or the } \\
\text { involvement of experts, technologies } \\
\text { from the outside }\end{array}$ \\
\hline $\begin{array}{l}\text { Updating, re-equipment of the } \\
\text { main production park, } \\
\text { intended for the production of } \\
\text { innovations }\end{array}$ & $\begin{array}{l}\text { Share of costs of updating / re- } \\
\text { equipment of production } \\
\text { capacities }\end{array}$ & $\begin{array}{l}\text { Implementation of new technologies, } \\
\text { production equipment for production of } \\
\text { innovative products }\end{array}$ \\
\hline $\begin{array}{l}\text { Increase in the labour } \\
\text { productivity }\end{array}$ & Productivity, \% \\
\hline $\begin{array}{l}\text { Growth in volumes of the } \\
\text { turned-out innovative } \\
\text { products }\end{array}$ & $\begin{array}{l}\text { Volume of the turned-out } \\
\text { innovative products, thousand } \\
\text { rubles }\end{array}$ & $\begin{array}{l}\text { To develop a motivational strategy of } \\
\text { workers, norms and expectations }\end{array}$ \\
\hline $\begin{array}{l}\text { Increase in the demand and } \\
\text { sale of innovations } \\
\text { for the production growth in volumes } \\
\text { commercialization of } \\
\text { innovative products, advertising } \\
\text { campaign, studying of the } \\
\text { market, competitors, taste and } \\
\text { preferences of clients and } \\
\text { consumers }\end{array}$ & $\begin{array}{l}\text { Introduction of marketing innovations, } \\
\text { enhanced action of marketing services at } \\
\text { the enterprise for all the stages of } \\
\text { innovative process. Formation of } \\
\text { marketing policy. Development of } \\
\text { actions for stimulation of marketing } \\
\text { specialists on the increase in demand for } \\
\text { innovations and their commercialization }\end{array}$ \\
\hline $\begin{array}{l}\text { Use of digital technologies at } \\
\text { all the stages of innovative } \\
\text { process }\end{array}$ & $\begin{array}{l}\text { Effect of the use of digital } \\
\text { technologies in all the } \\
\text { components of the innovative } \\
\text { process }\end{array}$ & $\begin{array}{l}\text { The use of digital technologies in } \\
\text { research, scientific, technological, } \\
\text { production, diffusion activity of the } \\
\text { enterprise }\end{array}$ \\
\hline
\end{tabular}

The purposes, indicators and actions of the basic scheme of BSI (Personnel) are presented in Table 4 [12]. 
Table 4. Purposes, indicators, actions for the "Personnel" projection

\begin{tabular}{|l|l|l|}
\hline \multicolumn{1}{|c|}{ Purpose } & \multicolumn{1}{c|}{ Indicators } & \multicolumn{1}{c|}{ Measures } \\
\hline $\begin{array}{l}\text { To increase the skill level } \\
\text { connection with the } \\
\text { production and realization } \\
\text { of innovations }\end{array}$ & $\begin{array}{l}\text { The relation of the } \\
\text { employees, who } \\
\text { underwent special } \\
\text { training, professional } \\
\text { development and / or } \\
\text { retraining to the total } \\
\text { quantity of the employees }\end{array}$ & $\begin{array}{l}\text { To provide training / retraining / } \\
\text { professional development of the } \\
\text { personnel. To provide the possibility } \\
\text { of the personnel training. To motivate } \\
\text { by the introduction of the coefficient, } \\
\text { taking into account training / } \\
\text { retraining / professional development } \\
\text { in the system of compensation }\end{array}$ \\
\hline $\begin{array}{l}\text { To increase the level of } \\
\text { creativity, innovation of } \\
\text { the personnel, idea men }\end{array}$ & $\begin{array}{l}\text { Share of personnel, able to } \\
\text { think, create, generate the } \\
\text { ideas creatively, to the } \\
\text { total quantity of the } \\
\text { personnel }\end{array}$ & $\begin{array}{l}\text { To create the atmosphere and } \\
\text { conditions for the creative and } \\
\text { innovative approach. Announcement } \\
\text { of various competitions. Awarding for } \\
\text { creativity and innovation at all the } \\
\text { stages of innovative process and } \\
\text { production of innovations. }\end{array}$ \\
\hline
\end{tabular}

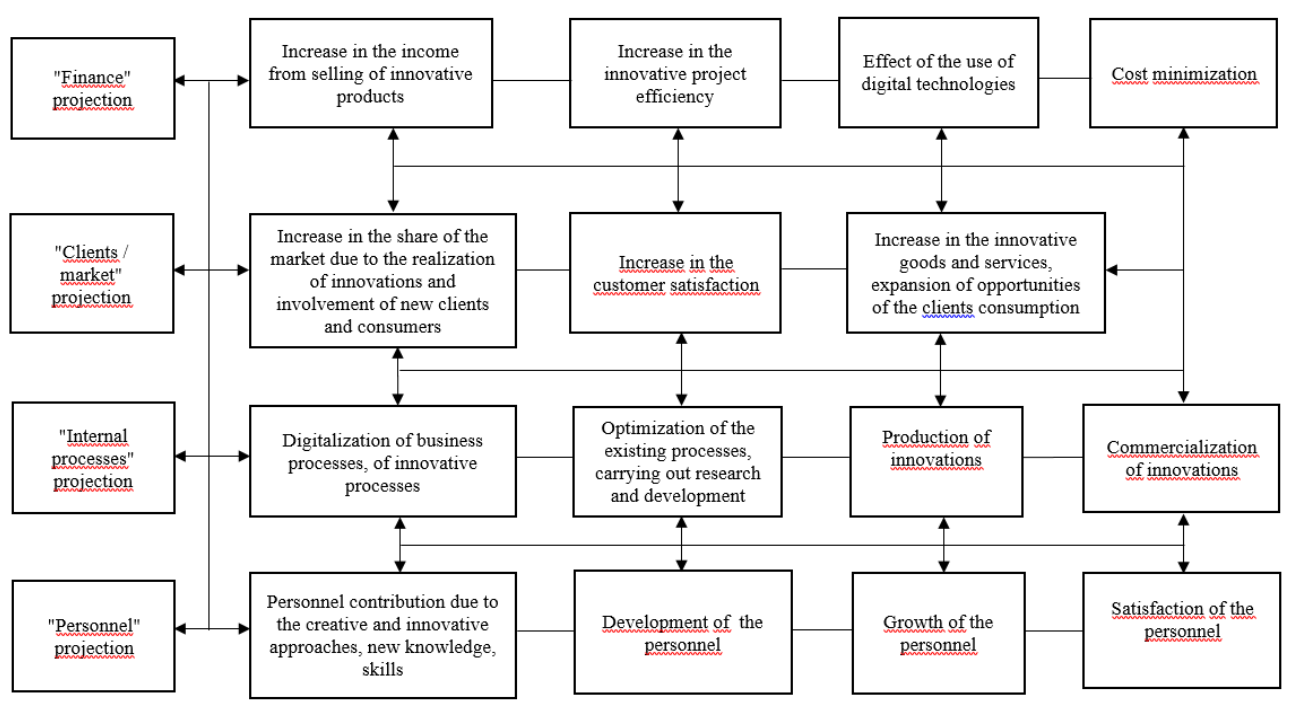

Fig. 1. Structural-and-logical scheme of BSI (Compiled by the authors)

\section{Results}

The offered structural logic diagram of the BSI is a good evident tool for the elaboration of strategy of innovative process management and for obtaining some effect of the innovative project implementation, where all the relationships of cause and effect allow not only developing an algorithm of the innovative process implementation, but also estimating the efficiency and revealing the factors and "bottlenecks", interfering the realization of the innovation. Thus, we receive an effectively balanced vision of the short and medium-term purposes, financial and non-financial performance of the innovative activity, indicators of leadership or lag in the main projections, determination of internal and external prospects $[13,14,15]$. That is why we use the BSI, which allow us not only to operate the effectiveness, but also to operate the interrelations of the innovative strategy of the enterprise and their realization for the continuous strategic development promote. Naturally, the enterprise can integrate and use the major indicators, for example, the increase in income, requirements 
satisfaction of clients and consumers, development of new products. But it is important to remember that all these indicators interconnected among themselves directly or indirectly, and thus the improvement of indicators of the top priority will lead to the improvement of other indicators.

\section{Discussion}

At the present stage of the development, the matters of the assessment of the innovative activity efficiency in groups of the uniform enterprises or industries remain relevant. In this regard, the authors plan the expansion of this approach to some specific industries of the national economy, considering the branch features [16]. In the subsequent research, it is planned to extend the author's approach to meso- and macro- levels. It is also planned to expand the projections of BSI and to consider them through the prism of the innovative process stages, where it will be possible to develop indicators and to carry out their assessment at each stage of the innovative process according to the types of economic activity [17]. It will allow developing the policy, strategic reference points and offering mechanisms of innovative process management in the industries. As a result, it will be possible to carry out the assessment of the efficiency and to create models of innovative processes on industries on the basis of the offered BSI, considering the industries features, and to improve management of them for obtaining industrial innovations.

\section{Conclusions}

The structural system of the balanced indicators is developed. The system is as optimum set of interconnected quantitative and qualitative, scientific and technical, operational, marketing indicator, reflecting the most important subsystems in a complex (finance, processes, clients and development) in the general system of activity of the organization of the construction industry. It allows the company to increase the probability of the achievement of the planned indicators of cost and social efficiency at the expense of more adequate (fast and exact) responses to the changes in the external environment. The balanced system of indicators increases the effectiveness of management in the organization, bringing behaviour of the specific employee into the optimum compliance with the tasks set by the management of the company.

\section{References}

1. V. Markova, Digital economy DOI: 10.12737/textbook_5a97ed07408159.98683294

2. A. Mottaeva, IOP Conf. Series: Earth and Environmental Science, 90, 012124 (2017) doi :10.1088/1755-1315/90/1/012124

3. G. Nazarova, N. Nazarov, Innovative Technologies and Scientific Solutions for Industries, 2(2), 132-137 (2017) DOI: https://doi.org/10.30837/25229818.2017.2.132

4. A. Batkovskiy et al., Mediterranean Journal of Social Sciences, 6(4) (2015) DOI: 10.5901/mjss.2015.v6n4s4p243

5. E. Elahi, Foresight, 15(2), 117-131 http://dx.doi.org/10.1108/14636681311321121

(2013) 
6. R. Taplin, (ed.). Risk Management and Innovation in Japan, Britain and the USA (Routledge, 2005)

7. N. P. Tereshina, A. V. Sorokina, Tenth International Conference "Management of Large-Scale System Development" (MLSD) (2017) DOI: 10.1109/MLSD.2017.8109694

8. A. H. Hanson, Public Enterprise and Economic Development (2019) DOI: 10.4324/9780429058981-8

9. I. Sokolova, N. Kolganova, S. Barbashova, A. Ovsyannikova, IOP Conference Series Materials Science and Engineering, 497, 012035 (2019), DOI: 10.1088/1757-899X/497/1/012035

10. M. A. Bahauovna, M. A. Bahauovna, International Journal of Applied Engineering Research, 11(9), 6808-6816 (2016)

11. E. Vasilyeva, MATEC Web of Conferences, 193, 01025 (2018) DOI: https://doi.org/10.1051/matecconf/201819301025

12. V. V., Zozulya, L. I. Goncharenko, A. V. Zuikov, G. N. Semenova, Journal of Advanced Research in Law and Economics, 8(5) (2017)

13. I. A. Markina, A. V. Sharkova, Journal of Applied Economic Sciences, 9(4), 687693 (2014)

14. Y. V. Morozyuk et al., Journal of Environmental Management and Tourism, 83(19), 507-515 (2017)

15. K. Kunanbayeva, A. Gorovoy, A. Butyrin, MATEC Web of Conferences, 193, 05048 (2018)

16. N. A. Kharitonova, E. N. Kharitonova, V. N. Pulyaeva, Advances in Intelligent Systems and Computing, 726, 1091-1100 (2019)

17. I. A. Markina, A. V. Sharkova, M. Y. Barna, International Journal of Entrepreneurship, 22(3) (2018) 